\title{
The Integrated Economic Model of Oil Field Development in the Context of New Industrialization
}

\author{
Olga Simchenko ${ }^{1}{ }^{*}$ Valery Grakhov ${ }^{1}$, Vadim Krivorotov ${ }^{2}$, Evgeny Chazov ${ }^{1}$,
}

\author{
Alexander Suntsov ${ }^{1}$
}

${ }^{1}$ Izhevsk State Technical University named after M.T. Kalashnikov, Russia

${ }^{2}$ Ural Federal University named after the first President of Russia B.N. Yeltsin, Russia

*Email: simchenko.ol@yandex.ru

\begin{abstract}
In the context of the new industrialization, the issues related to the search for the optimal option for the field's development are genuinely relevant. The article is devoted to creating an integrated economic model of oil-field development, allowing under the chosen development strategy, to achieve maximum cash flow at the site for the planned period, significantly improve the quality and validity of management decisions in oil companies.

The article examines the theoretical aspects of economic modelling from the perspective of system thinking and emphasises its importance. It is noted that the conceptual basis for understanding economic modelling can be a system of rational, evolutionary and cognitive aspects.

The results of creating a scheme of the complex economic model generated report on technical-economic indicators of field development according to the chosen strategy of development (on the example of Kotovskoe field in the Udmurt Republic), representing two sets of figures with graphic applications.

In conclusion, a comparison is made between the economic efficiency of the actually implemented program and the calculated model, which allows achieving the maximum cash flow for the field over the planned period, increasing the company's income, and reducing the risk of making a non-optimal management decision on the development of the field.
\end{abstract}

It is concluded that the stages of the developed economic model can be transposed to the calculation of any field.

Keywords: Economic model, Oil field, New industrialization, System thinking, Production program, Development strategy.

\section{INTRODUCTION}

Deciding to invest in projects for the development of an oil field is quite a difficult task. The implementation of such projects is influenced by risk factors such as relatively high initial investment requirements, long-term investment horizons (projects can last up to 20 years or more) and negative cash flow during the first few years, sometimes also in the last years of the project life. These factors, combined with dangerously volatile price levels, increase the amount of uncertainty in the data used when management makes decisions about investing in oil projects.
Most oil companies decide to invest in field development projects based on economic models built as tables prepared by specialists of financial and economic services or external experts based on data available from various sources (for example, oil engineers, geologists, etc.). These models are characterised by vague definitions of the input variables and how they relate to the output parameters. Therefore, to improve the decision-making process in the oil investment projects and be able to address contemporary challenges, it is necessary to develop a comprehensive economic model considering management decisions on the development of the field and of the whole enterprise, which provides 
common principles for the selection of projects in the investment portfolio.

This model's central component is the new industrialization, designed to provide an intensive type of expanded reproduction of the oil-producing enterprise, forming an optimal production program for the field under the chosen development strategy, achieving the field's maximum cash flow [1].

This work aims to create a comprehensive economic model for developing an oil field in the context of new industrialization

The goal identified the need to solve several tasks:

- to reveal the theoretical aspects of economic modelling from the point of view of system thinking;

- to form a scheme for constructing a complex economic model for the development of an oil field in the conditions of new industrialization, to present the main stages of calculation;

- generate a report on the technical and economic indicators of the field development according to the selected development strategy;

- calculate the economic effect of using the model.

The object of the study is the Kotovskoe oil field on the territory of the Udmurt Republic.

The study's subject is the organisational and economic relations that arise in forming a complex economic model for the development of the Kotovskoe oil field in the Udmurt Republic territory under new industrialization conditions.

\section{THEORETICAL ASPECTS OF ECONOMIC MODELLING}

Economic modelling theory encompasses an extensive literature that contributes to the understanding of various types of systems. However, for this article's purposes, we will focus on systems thinking as a framework for encapsulating the key principles of systems theories relevant to economic models' development (D. Cabera, L. Cabera, E. Powers, 2015; G. Midgley, 2003) [2,3].

The first mention of economic models should be attributed to the 40-60 years of the 20th century (Lange, 1947; Bellman et al., 1957; Jones, 1960) [4]. Simultaneously, the first practice-oriented models opened new horizons in developing organisations' economy and were of great value to customers and consumers (Konczal, 1975) [5].

The formation of economic models and their evolution is closely related to the development of strategic management schools (Martins et al., 2015) [6]. The three main views underlying the school of rational positioning, the evolutionary school, and the cognitive school are relevant to economic models' development.

The school of rational positioning assumes that an economic model is a purposefully developed system that reflects rational management, choice, and the consequences of such option in the formalised description of various economic phenomena and processes (Zott and Amit, 2010; Casadesus-Masanell and Ricart, 2010) [7, 8]. Simultaneously, the rational view emphasises the importance of deductive thinking in developing and developing economic modelling. However, in the conditions of the dynamic external environment and the transition to new industrialization, particularly with the development of recent technological trends, such a rational and deductive approach can be problematic since it provides the need to follow formal indicators' planned values.

The evolutionary school develops as a result of local search in response to problems and opportunities. It considers the evolution of the model in the economy as the result of initial experiments with subsequent transformation based on "trial and error" learning (Sosna et al., 2010) [9]. This approach emphasises changes in the external environment as an incentive for subsequent transformations. However, the external environment may not be objective, and the models themselves of representatives of the evolutionary school are complicated to analyse. Therefore, there are problems with understanding what lies behind the model constructions.

The position of the authors of the cognitive school ( $\mathrm{L}$. Martins et al., 1992, Doz and Kosonen, 2010; McGrath, 2010; Teece, 2010) $[6,10,11,12]$ is that economic models are based on a mental schema that allows them to cope with complexities. Therefore, the model is a cognitive process that simplifies the knowledge of various economic phenomena and adjusts within the limits of computing power to search for the most effective solutions. In this context, the cognitive school emphasises analogies' power when conceptual or rulebased knowledge is not available.

The number of economic models currently in use is undoubtedly huge. The specific assumptions used, and the level of detail used vary greatly depending on the problem being solved. For example, the types of models used to explain the overall economic efficiency level in knowledge-intensive and multi-nomenclature industries should be significantly more aggregated and complex.

Thus, in the works of Yu.S. Vykhodets, N.Yu. Rovinskaya, the economic model, is considered from the perspective of the organisation's behavioural aspect within the interaction framework, as a complex system of actions and relationships [13].

From the point of view of V.I. Vagizova and K.V. Selivanova, the business model is a particular 
management concept focused on the search, motivation, and creation of conditions for interaction between institutions of the domestic economy's real and financial sectors in the context of reindustrialization [14].

However, despite the existing variety of interpretations to understand the economic model's essence, this concept's theoretical aspects are not fully understood. In particular, it has not been studied how cognitive aspects can affect the economic model's structure.

An analysis of the literature on systems analysis in economics provides the basis for linking the cognitive point of view to various details - the model's entire structure.

Thus, understanding the current opportunities that allow economic models to develop is essential, both from research and management perspectives. Our study provides a preliminary conceptual understanding through the lens of systems thinking of how rational, evolutionary, and cognitive aspects can be the basis for understanding modelling and emphasises that an economic model can be viewed as a complex system of relevant phenomena and processes to study the general patterns and properties of economic systems. And systems thinking provides a preliminary understanding of how these models evolve.

\section{RESULTS OF THE STUDY THE SCHEME FOR BUILDING THE MODEL. CALCULATION STEPS}

The oil and gas industry has always been associated with significant capital expenditures, which have more than doubled in real terms under the new industrialization. Not only scientists but also practitioners pay great attention to this area.

A detailed analysis of the theoretical aspects of economic modelling presented above allowed the authors to propose a comprehensive economic model for developing an oil field.

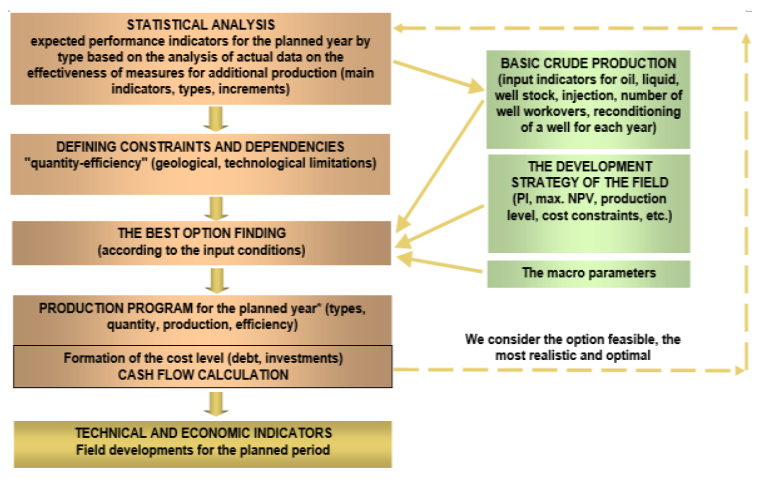

Figure 1 scheme for the building of the model. Calculation steps. Source: Compiled by the author.
The main stages of the complex economic model of field development can be presented schematically as follows (figure 1).

The first stage of building the model is to perform a statistical analysis under the activities carried out in previous periods at a particular field and focused on obtaining additional oil production.

The expected performance indicators for the upcoming period activities' types are calculated based on the actual data. The obtained data allow us to calculate both private indicators and key business indicators for oil projects [15].

The next step is to identify various restrictions and dependencies, without which it is impossible to form a production program as close to real conditions as possible, such as:

- geological: availability of candidate wells, coverage of geological and technical measures (GTM), project fund of wells, etc.;

- technological: restrictions on infrastructure, the capacity of on-site facilities, pipelines, etc.;

- economic: economic efficiency, profitability, risk degree (success), etc.

The search for dependences of the effectiveness of planned measures in the context of "quantity-efficiency", in turn, is based on actual data, expert assessments for future periods, and the presence of candidate wells. The base production calculation is based on the input indicators for the level of oil, liquid production, the fund of producing and injection wells, the injection level, the number of wells maintenance and workovers (WMWO) attributed to the base.

For typical GTM projects (optimisation, reperforation, etc.), the following calculation scheme is proposed (figure 2 ). The quantitative values in figure 2 and further study are presented on the Kotovskoe field example in the Udmurt Republic.

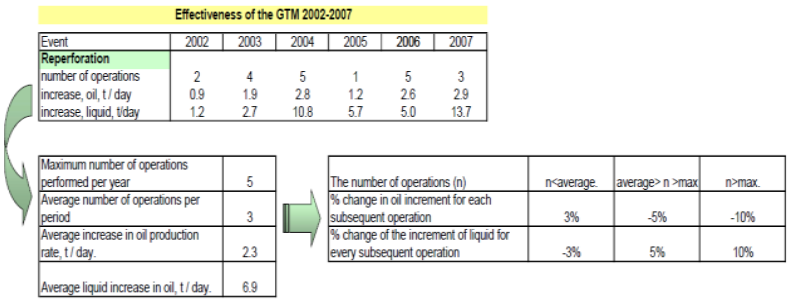

Figure 2 Scheme for determining the effectiveness of typical GTM. Source: Compiled by the author.

Based on the actual data, the maximum number of operations for this type carried out at this field, the average number of operations for the analysed period, the average initial increase in the flow rate from oil and liquid from the GTM is determined. 
Based on these data, the dependence of the effectiveness on the number of measures is built.

Having a field database, the third stage is used to calculate the production program's optimal option that corresponds to the chosen field development strategy. The calculation considers real macro parameters; each event's cost is taken following the upcoming year's business plan. The calculated version of the production program is deemed feasible, the most realistic and optimal, and we will calculate the next year. The calculated year passes into statistics and is then used to generate input data for the next year. We move on to the calculation of the next year. The number of periods for the calculation by the model is unlimited. The result of all calculations is the technical and economic indicators of this field's development for the entire planned period.

When forming variants of production programs (stage 4 of the model), the model identifies several strategies, possible directions for the development of the field (enterprise), namely:

1) economic efficiency - setting a limit value for PI selecting only those projects that achieve efficiency on the profitability index of at least the specified value;

2) a certain level of oil (liquid) production with a maximum NPV - selecting the maximum number of operations for each option with NPV $>0$ that reach a given level of production, finding the best combination of projects that provides the maximum cash flow;

3) the maximum cash flow is the implementation of all projects for each type until each of the additional operations reaches an efficiency of $\mathrm{PI}>1$;
4) the maximum investment budget with the maximum NPV is the selection of the maximum number of operations for each option with NPV $>0$, which do not exceed the specified cost level in total, and the search for the best combination based on the maximum investment level that provides the maximum cash flow [16].

\section{FORMATION OF A REPORT ON THE TECHNICAL AND ECONOMIC INDICATORS OF THE FIELD DEVELOPMENT ACCORDING TO THE SELECTED DEVELOPMENT STRATEGY}

Following the integrated economic model of field development presented in figure 1, technical and economic indicators are calculated under the selected development strategy. The result of this calculation should be a report that represents two blocks of indicators with graphical applications. The first shows the production program directly by type of activities by year (quantity, the initial increase in oil and liquid debits), the level of oil production, the fund of wells, etc., the second shows the level of income and expenses, cash flow, profitability index, net discounted income from the implementation of the formed program.

The type of report on the technical and economic indicators of the field development option (for example, the Kotovskoe field in the Udmurt Republic) is shown in figure 3 .

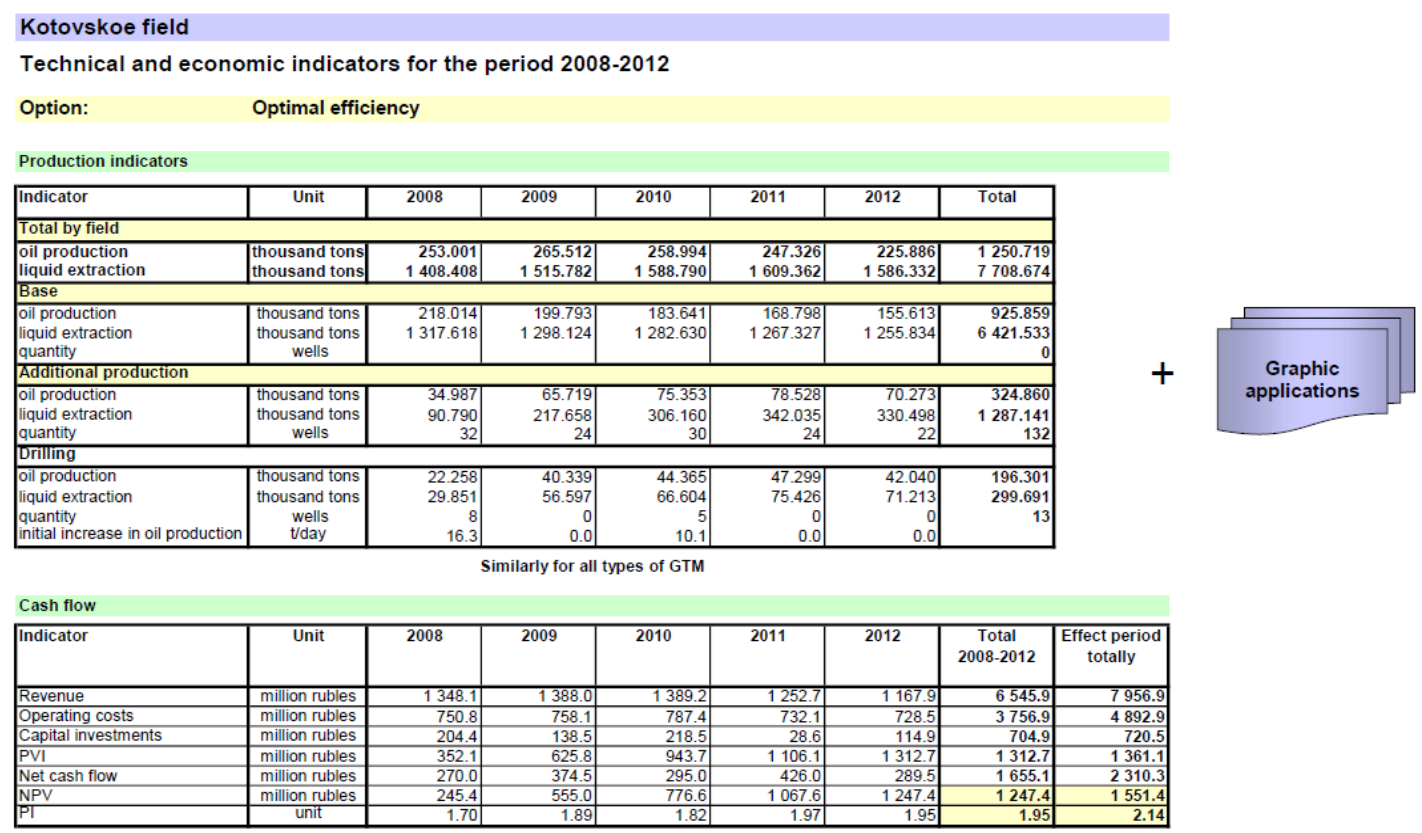

Figure 3 View of the report on the technical and economic indicators of the field development option. Source: Compiled by the author using the materials of the source [17]. 
Table 1. Production program for the Kotovskoe field, considering the strategy for achieving maximum efficiency

\begin{tabular}{|c|c|c|c|c|}
\hline \multicolumn{5}{|c|}{ Production program } \\
\hline Event & Unit & Fact, 2015 & $\begin{array}{c}\text { Calculation } \\
\text { based on the } \\
\text { model }\end{array}$ & Deviation \\
\hline \multicolumn{5}{|l|}{ Drilling } \\
\hline number & wells & 1 & 1 & \\
\hline oil & t/day & 15,7 & 15,7 & \\
\hline liquid & t/day & 16,5 & 16,5 & \\
\hline \multicolumn{5}{|l|}{ BHT } \\
\hline number & wells & 6 & & -6 \\
\hline oil & t/day & 2,12 & & $-2,12$ \\
\hline liquid & t/day & 5,6 & & $-5,6$ \\
\hline \multicolumn{5}{|l|}{ Optimisation } \\
\hline number & wells & 3 & 6 & 3 \\
\hline oil & t/day & 4,5 & 4,3 & $-0,2$ \\
\hline liquid & t/day & 19,9 & 20,9 & 1,0 \\
\hline \multicolumn{5}{|l|}{ Hydraulic fracturing } \\
\hline number & wells & 2 & 3 & 1 \\
\hline oil & t/day & 9,0 & 8,7 & $-0,3$ \\
\hline liquid & t/day & 55,0 & 54,8 & $-0,2$ \\
\hline \multicolumn{5}{|l|}{$A P G$} \\
\hline number & wells & & 1 & 1 \\
\hline oil & t/day & & 2,8 & 2,8 \\
\hline liquid & t/day & & 3,6 & 3,6 \\
\hline \multicolumn{5}{|l|}{$R / W$} \\
\hline number & wells & 1 & 2 & 1 \\
\hline oil & t/day & 4,8 & 4,6 & $-0,2$ \\
\hline liquid & t/day & 8,5 & 8,1 & $-0,4$ \\
\hline \multicolumn{5}{|l|}{ Reperforation } \\
\hline number & wells & 3 & 5 & 2 \\
\hline oil & t/day & 2,9 & 2,8 & $-0,1$ \\
\hline liquid & t/day & 13,7 & 14,1 & 0,4 \\
\hline
\end{tabular}

Source: Compiled by the author using materials of source [17]

\section{THE ECONOMIC EFFECT OF USING THE MODEL}

Modelling the possible production program in Kotovskoe field of OJSC Udmurtneft for 2019 based on the strategy of maximum efficiency (table 1), a comparison of economic efficiency programs are actually implemented and calculated by the model (the calculation was carried out in a single model, ceteris paribus) (table 2). Under the calculated production program model, oil production is 3,133 thousand tons higher than the actual production for 2015 (about $26 \%$ of the additional annual production) and 13.8 thousand tons over the five years. Simultaneously, the program requires more operating costs by 6.2 million rubles and capital investments by 3.5 million rubles. But in the end, the NPV for the field for the period of the effect of the proposed operations exceeds the actual one by 20.1 million rubles. This circumstance is because the model when forming the program, chose the most economically effective measures from the possible practical ones, selected the best combination of projects that bring the maximum technological and economic effect [18].

\section{CONCLUSIONS}

In this work, we have achieved the following scientific results. The theoretical aspects of economic modelling are studied. The main schools that have made the most significant contribution to economic models' development are identified: the school of rational positioning, the evolutionary and cognitive schools. Despite some scientific community's progress in studying the economic model concept's substantive foundation, several unresolved problems significantly complicate its use in business practice.

As a basis for the development of economic models, the authors propose to use system thinking. Simultaneously, it is suggested to consider the economic model as a complex system of relevant phenomena and processes to study economic systems' general laws and properties.

A scheme for constructing a complex economic model has been formed, which provides an opportunity in the conditions of new industrialization to increase the 
Table 2. Comparison of the economic efficiency of the actually implemented program and the calculated model

\begin{tabular}{|l|l|c|c|c|c|c|c|}
\hline \multicolumn{2}{|c|}{ Indicator } & Unit & $2015-2019$ & $\begin{array}{c}\text { Effect } \\
\text { period }\end{array}$ & $\begin{array}{c}\text { Model option } \\
2015-2019\end{array}$ & $\begin{array}{c}\text { Model } \\
\text { option } \\
\text { Effect period }\end{array}$ & $\begin{array}{c}+/- \\
+/- \\
2015-2019\end{array}$ \\
\hline $\begin{array}{l}\text { Effect } \\
\text { period }\end{array}$ \\
\hline Oil production & $\begin{array}{l}\text { thousan } \\
\text { d tons }\end{array}$ & 1799,3 & 1800,8 & 1813,1 & 1814,7 & 13,8 & 13,9 \\
\hline Liquid extraction & $\begin{array}{l}\text { thousan } \\
\text { d tons }\end{array}$ & 16621,6 & 16623,4 & 16732,0 & 16734,0 & 110,4 & 110,6 \\
\hline Investment (OPEX) & $\begin{array}{l}\text { million } \\
\text { rubles }\end{array}$ & 1064,7 & 1071,2 & 1070,9 & 1077,4 & 6,2 & 6,2 \\
\hline Capital investments & $\begin{array}{l}\text { million } \\
\text { rubles }\end{array}$ & 376,5 & 376,5 & 379,9 & 379,9 & 3,5 & 3,5 \\
\hline PVI & $\begin{array}{l}\text { million } \\
\text { rubles }\end{array}$ & 1075,5 & 1078,5 & 1084,1 & 1087,1 & 8,6 & 8,6 \\
\hline NPV & $\begin{array}{l}\text { million } \\
\text { rubles }\end{array}$ & 2394,6 & 2414,8 & 2414,4 & 2434,9 & 19,9 & 20,1 \\
\hline PI & unit & 3,23 & 3,24 & 3,23 & 3,24 & 3,31 & 3,34 \\
\hline
\end{tabular}

Source: compiled by the author using materials of source [17].

economic efficiency of field development through a comprehensive analysis, to achieve the maximum cash flow for the field over the planned period, and, consequently, to increase the company's income, while reducing the risk of making a non-optimal management decision on field development for the planned period based on the development strategy.

The universality of the model lies in the fact that the principles of constructing dependencies and constraints; the calculation stages can be transposed to the calculation of any field.

The results of creating a scheme of the complex economic model generated report on technical-economic indicators of development of the Deposit according to the chosen strategy of development on the example of Kotovskoe field in the Udmurt Republic.

\section{REFERENCES}

[1] S. Gubanov, Sovereign breakthrough. Neoindustrialization of Russia and vertical integration, S. Gubanov, M.: World of books, 2012, $224 \mathrm{p}$.

[2] D. Cabera, L. Cabera, E. Powers, A unifying theory of systems thinking with Psychological applications, Systems Research and Behavioural Science 32 (2015) 534-545.

[3] G. Midgley, Systems Thinking. Sage Publications: Thousand Oaks, CA, 2003.

[4] S.V. Orekhova, Industrial enterprises: Electronic VS. Traditional Business Model, Terra economicus, Iss. $\quad 4(16), \quad 2018, \quad$ DOI: https://doi.org/10.23683/2073-6606-2018-16-4-77$\underline{94}$
[5] A.I. Tatarkin, A.A. Kuklin, O.A. Romanova, L.N. Cheremnykh, V.I. Yakovlev, Neutralisation of threats to the regional economic system's economic security with a translation to the "model of sustainable development", Report on R \& D, Iss. 9706-80351, 1997.

[6] L.L. Martins, V.P. Rindova, B.E. Greenbaum, Unlocking the hidden value of concepts: A cognitive approach to business model innovation. Strategic Entrepreneurship, Journal 9 (2015) 99-117.

[7] C. Zott, R. Amit, Business model design: An activity system perspective. Long Range Planning 43(2-3) (2010) 216-226.

[8] R. Casadesus-Masanell, J.E. Ricart, From strategy to business models and onto tactics. Long Range Planning 43(2-3) (2010) 195-215.

[9] M. Sosna, R.N. Trevinyo-Rodriguez, S.M. Velamuri, Business model innovation through trialand-error learning. Long Range Planning 43(2-3) (2010) 383-407.

[10] Y.L. Doz, M. Kosonen, Embedding strategic agility: A leadership agenda for accelerating business model renewal. Long Range Planning 43(2-3) (2010) 370-382.

[11] R.G. McGrath, Business models: A discoverydriven approach. Long Range Planning 43(2-3) (2010) 247-261.

[12] D. Teece, Business models, business strategy and innovation. Long Range Planning 43(2-3) (2010) 172-194. 
[13] Yu.S. Vykhodets, Application of the term "business model" for analysing and describing the company's activities, Economics and Management of machinebuilding industry enterprises: Problems of Theory and Practice 1(21) (2013) 65-76.

[14] K.M. Selivanova, Behavioural business models of interaction between the real and financial sectors of the economy in the context of restructuring, dissertation...Candidate of Economic Sciences: 08.00.05, 2015, $280 \mathrm{p}$.

[15] R.V. Faizullin, O.M. Perminova, Model of stock control at scrap at processing enterprises, Acta Logistica 7(1) (2020) 61-64.

[16] I. Chichenkov, R. Faizullin, Development of a KPI system for pig farms based on the criteria for evaluating the efficiency of the enterprise. In IOP Conference Series: Earth and Environmental Science Vol. 548, Iss. 2, p. 022019, IOP Publishing (2020, August).

[17] Annual report of PJSC "NC "Rosneft" for 2019 Retrieved from the Internet address Sze, S.M. (2019), Physics of Semiconductor Devices. Retrieved from: https://www.rosneft.ru/upload/site1/document_file/ a_report_2019.pdf

[18] V.V. Krivorotov, A.V. Kalina, Z.S. Belyaeva, S.Y. Erypalov, World Review of Entrepreneurship, Management and Sustainable Development Vol. 12 Iss. 2-3 (2016) 254-269. 